\title{
Town Lake Bottom Sediments: A Chronicle of Water- Quality Changes in Austin, Texas, 1960-98
}

One of the most spectacular fish kills of recent years occurred in the Colorado River below Austin, Texas, in 1961. Shortly after daylight on Sunday morning, January 15, dead fish appeared in the new Town Lake in Austin and in the river for a distance of about 5 miles below the lake. None had been seen the day before. On Monday there were reports of dead fish 50 miles downstream. ... By January 21, fish were being killed 100 miles downstream .... During the last week of January the locks on the Intracoastal Waterway were closed to exclude the toxic waters from Matagorda Bay and divert them into the Gulf of Mexico.

... investigators in Austin noticed an odor associated with the insecticides .... The manager of the (chemical) plant admitted that quantities of powdered insecticide had been washed into the storm sewer recently and, more significantly, he acknowledged that such disposal of insecticide spillage and residues had been common practice for the past 10 years.

.... For 140 miles downstream from the lake the kill of fish must have been almost complete, for when seines were used later in an effort to discover whether any fish had escaped they came up empty. Dead fish of 27 species were observed, totaling about 1000 pounds to a mile of riverbank.

Rachel Carson, 1962, Silent Spring

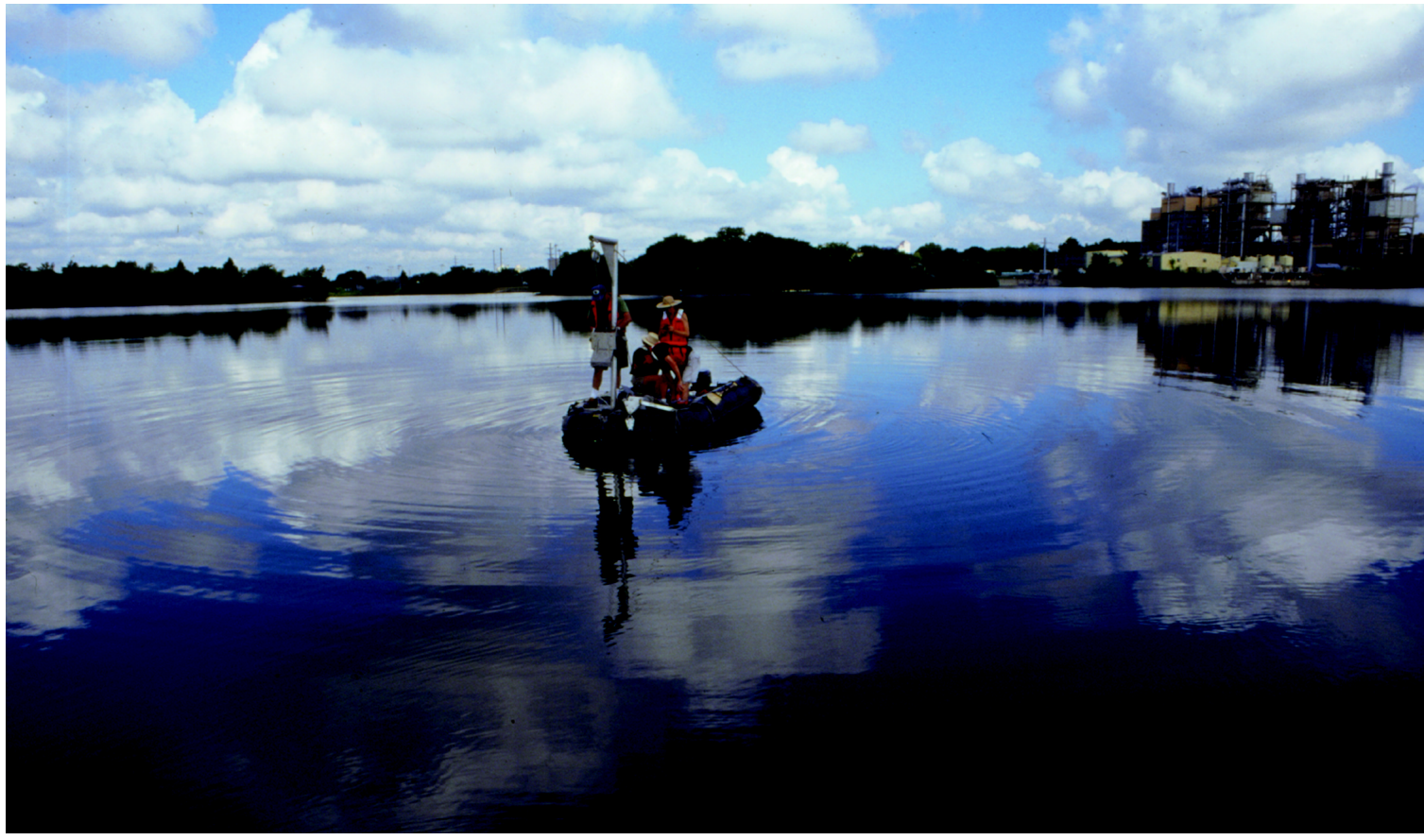

Town Lake, the last in the chain of Highland Lakes on the Colorado River, runs through the center of Austin, Texas. On any given day, grebes and coots dot the water, rowers skim alongside, and the sparkle of the sun on the water can be admired from the adjacent hike and bike path and from the windows of nearby office buildings. During the summer months, crowds gather along the shores of Town Lake to watch as many as 1 million Mexican Free-Tail bats emerge from under the Congress Avenue bridge. But below the lazily moving azure water lies a bed of sediment about 1 meter $(\mathrm{m})$ thick - sediment that has been deposited gradually since the reservoir was formed in 1959 and that has been recording changes in water quality since that time. What can this sediment tell us about the history of water quality in the Colorado River? And what does it say about the effects of the rapid urbanization of Austin and the future health of our environment? 


\section{What We See in Town Lake}

To answer these questions, the U.S. Geological Survey (USGS), in cooperation with the City of Austin, collected a sediment core in 1998 (collection methods explained in "How We Sample"). The core penetrated the entire $1 \mathrm{~m}$ of Town Lake sediment and contains evidence of the 1961 DDT spill described in "Silent Spring." The graph below (fig. 1a) shows DDT and its breakdown products, DDD and DDE, measured in the core. The large peaks near the bottom of the core mark the 1961 spill. Concentrations jump sharply from the first sample at the bottom of the core to the next sample up, estimated to date from 1961, then go even higher in the sample dated as 1963. Since 1963, total DDT concentrations $(\mathrm{DDT}+\mathrm{DDD}+\mathrm{DDE})$ in the lake sediment have decreased 90 percent, from 430 micrograms per kilogram $(\mu \mathrm{g} / \mathrm{kg})$ at the peak to $42 \mu \mathrm{g} / \mathrm{kg}$ in sediment deposited in 1998.

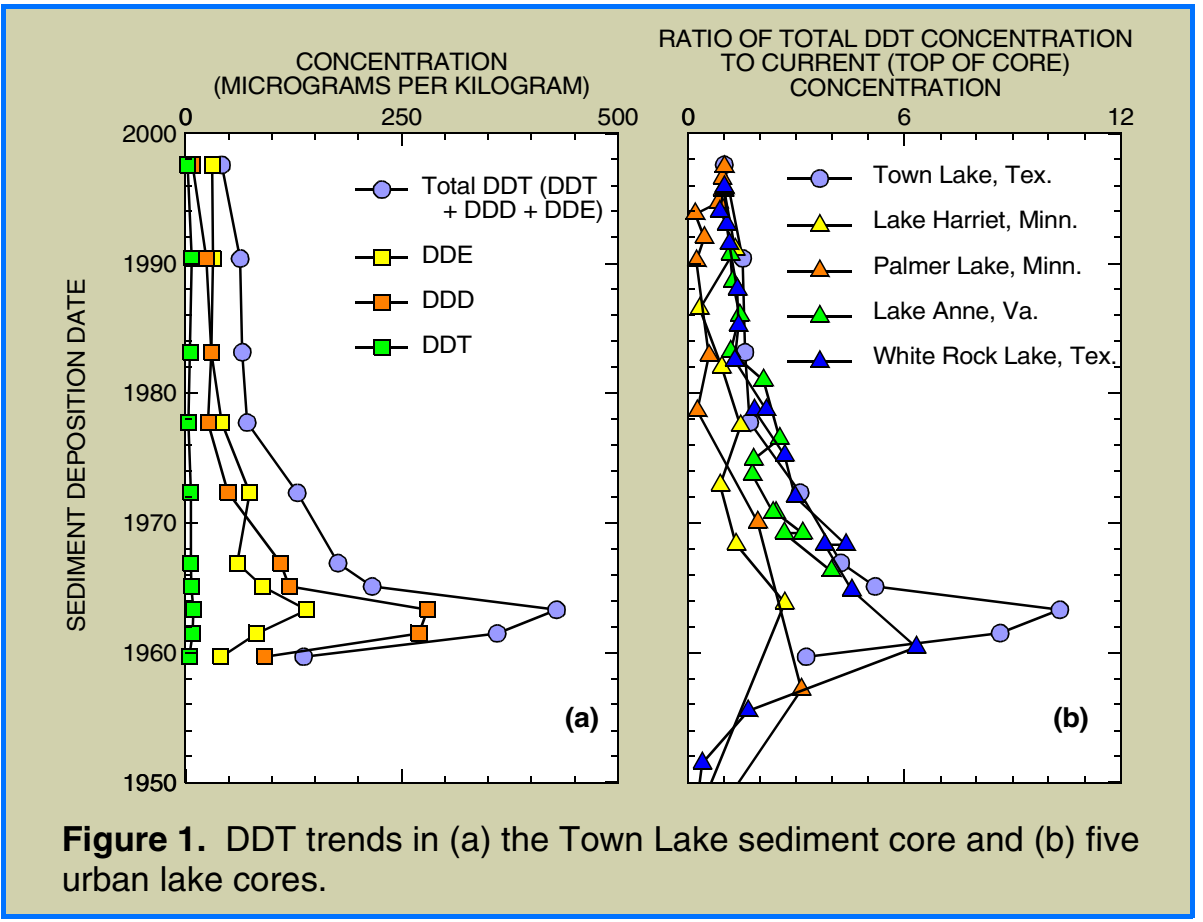

DDT use was ubiquitous in the United States in the 1950s and 1960s, and sediment cores from many lakes show a large DDT peak in the early 1960s (Van Metre and others, 1998). Is the peak in Town Lake any different? One way to find out is to compare the DDT trend in the Town Lake core with DDT trends in other urban lakes and reservoirs (fig. 1b). The peak concentration in Town Lake is about 10 times greater than the concentration in newer sediment at the top of the core. The average peak in the four other lakes compared on figure $1 \mathrm{~b}$ is four times greater than concentrations in newer sediment. This comparison indicates that the spill in Town Lake left behind DDT concentrations that are two to three times the concentrations that might be expected on the basis of "normal" DDT use in the 1950s and 1960s.

Historical use of other hydrophobic (incapable of dissolving in water; literally, "water fearing") contaminants are also recorded in the Town Lake sediments-in particular, lead and the organic compounds polychlorinated biphenyls (PCBs), chlordane, and polycyclic aromatic hydrocarbons (PAHs) (fig. 2). Like DDT, use of lead and PCBs was widespread during the early years of Town Lake but subsequently was reduced or eliminated by regulatory action. Chlordane, although restricted by regulatory action, remains at relatively high concentrations in recent sediments. In contrast, PAHs, which originate from numerous urban sources, are not regulated.

Lead concentrations in the Town Lake sediment core follow a trend pattern similar to that shown by other urban U.S. lakes. Lead in gasoline caused large increases in lead concentrations in urban lakes and streams in the 1960s and early 1970s. Lead concentrations peaked in urban reservoir and lake cores in the mid-1970s and then decreased with the introduction of unleaded gasoline (Callender and Van Metre, 1997). Concentrations in the Town Lake core have decreased by about 70 percent since 1970 (fig. 2a), a direct and encouraging response to the elimination of lead in gasoline.

PCBs had widespread industrial and commercial uses, primarily as insulation fluids for transformers and in appliances. PCB concentrations in sediment from most urban lakes peaked in the mid-to-late 1960s, at the height of their use, then decreased following restrictions imposed in 1971 (Van Metre and others, 1997, 1998). The pattern in Town Lake is similar, with a peak concentration of $96 \mu \mathrm{g} / \mathrm{kg}$ in the early 1960s decreasing by about 70 percent to $31 \mu \mathrm{g} / \mathrm{kg}$ in 1998 (fig. 2b). Thus, for these persistent contaminants (DDT, lead, PCBs), restricting their use has resulted in large decreases in Town Lake.

Chlordane is an organochlorine pesticide of the same general class as DDT. Use of most organochlorine pesticides was restricted or banned in the 1970s. Agricultural use of chlordane was restricted in 1974; however, urban use (primarily for termites and ants) was permitted until 1988. Even after 1988, use of existing stocks in the possession of home owners was allowed. On the basis of a nationwide survey of pesticide use in 1990, this continued use was substantial, rivaling the 


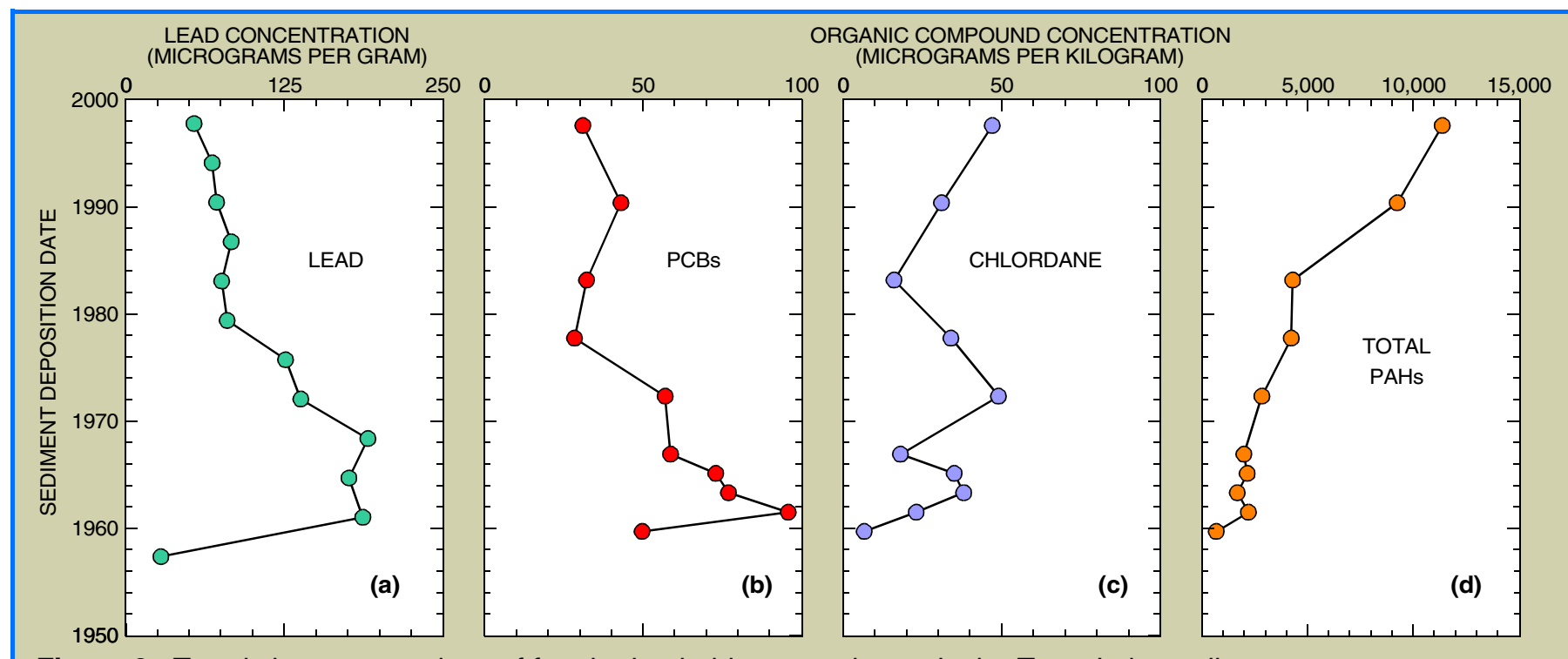

Figure 2. Trends in concentrations of four hydrophobic contaminants in the Town Lake sediment core.

early-1970s agricultural use (Whitmore and others, 1992). Chlordane is of particular concern in Town Lake; high levels of chlordane in fish have resulted in a fish consumption advisory imposed by the Texas Department of Health (1996). Chlordane concentrations in Town Lake sediment were relatively high in the 1960s and early 1970s, then decreased in the 1980s (fig. 2c). A small peak in the early 1960s, coincident with the DDT spill, possibly could indicate some chlordane released by the spill. A second peak in the early 1970s was coincident with substantial agricultural use in the United States and with chlordane peaks in some other urban (Van Metre and others, 1998) and agricultural (Van Metre and others, 1997) reservoir and lake cores. More surprising is the increase at the top of the core, indicating continued input of chlordane to Town Lake in the 1990s. Recent input was confirmed by analysis of suspended-sediment samples collected by the USGS in Shoal Creek (tributary to Town Lake) in November 1997 and March 1999. Chlordane concentrations in 10 suspendedsediment samples ranged from 9 to $340 \mu \mathrm{g} / \mathrm{kg}$ (U.S. Geological Survey, Austin, Tex., unpub. data), compared to a concentration of $47 \mu \mathrm{g} / \mathrm{kg}$ at the top of the Town Lake sediment core.

PAHs, in contrast to trends in the regulated or banned contaminants, show dramatic increases during the past 20 years in the Town Lake core (fig. 2d). This pattern is repeated, to varying degrees, in lakes with urbanizing watersheds across the United States (Van Metre and Callender, 1999). PAHs are trace contaminants that occur naturally in crude oil, coal, and other hydrocarbons. They also are produced by combustion of hydrocarbons, resulting in many urban sources including: industrial and power plant emissions; car and truck exhaust; tires; and asphalt roads and roofs. Eliminating PAHs from urban runoff is difficult because of their varied sources. PAHs are an environmental concern because they are toxic

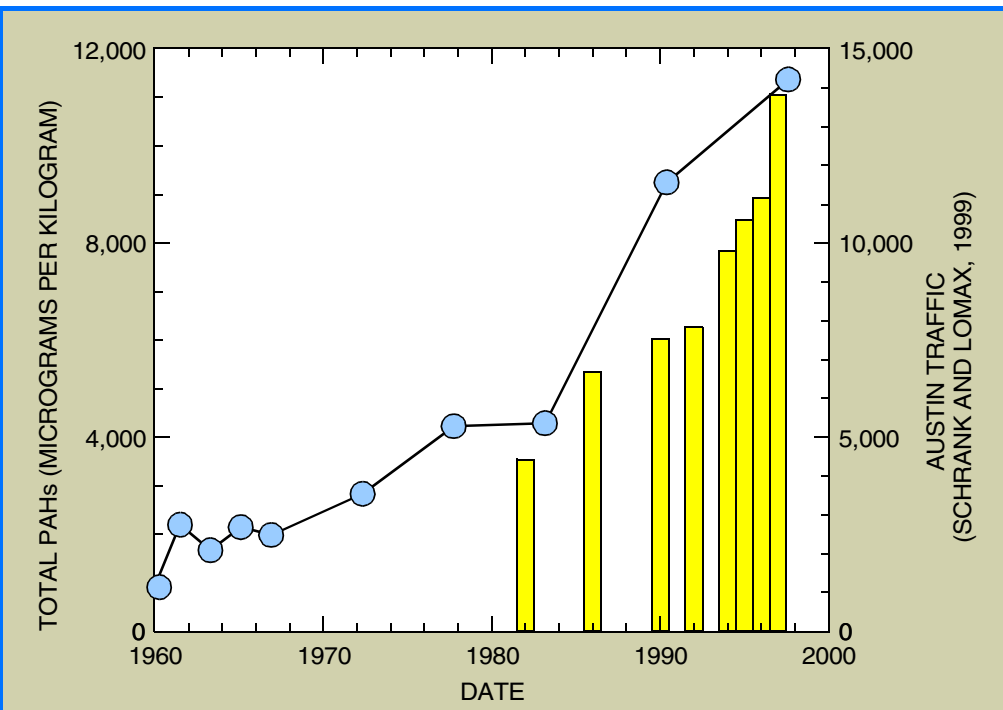

Figure 3. Comparison of Town Lake PAHs and traffic trends. to aquatic life and because several are suspected carcinogens (Björseth and Ramdahl, 1985; Long and Morgan, 1990).

Total PAH concentrations in recently deposited sediment in Town Lake are about 16 times the concentrations in 1960, increasing from about $700 \mu \mathrm{g} / \mathrm{kg}$ in 1960 to $11,400 \mu \mathrm{g} / \mathrm{kg}$ in 1998 (fig. 2d). The increase corresponds with increases in traffic in greater Austin (Schrank and Lomax, 1999; fig. 3). From 1982 to 1996, PAH concentrations in the sediment core and automobile use (expressed as total miles driven on Austin roads) both increased by about 2.5 times (fig. 3). The relation of PAH concentrations to Austin traffic is evidence of the importance of nonindustrial sources of PAHs to streams and lakes and indicates that vehicle emissions, road and tire wear, and engine oil leaks could be major sources of PAHs. 


\section{Overall Trends}

The trends in the Town Lake sediment core tell us that, in some respects, water quality is improving in the Colorado River in Austin. These decreasing trends are obviously good news. The decreasing trends in DDT, lead, and PCBs coincide with regulatory restrictions, often combined with voluntary reductions in use resulting from public awareness and concern.

Unfortunately, not all the contaminant trends in the Town Lake core are decreasing, chlordane and PAHs being obvious examples. Sales of chlordane have been banned since 1988; however, it could take years for concentrations to drop substantially. It is taking an average of about 10 years for persistent contaminants like DDT and chlordane to decrease by one-half in U.S. reservoirs and lakes (Van Metre and others, 1998). The picture is more troubling for PAHs, which are unregulated. The correlation of PAH concentrations to traffic rates in the Town Lake watershed (fig. 3) implies that limiting waterquality degradation in urbanizing lakes and streams might not be achieved by controlling land-use practices if traffic volume continues to grow unchecked.

Overall trends in sediment quality in Town Lake are not immediately apparent because both increasing and decreasing trends occur. The different groups of contaminants were compared by normalizing (dividing) all contaminant concentrations by the Canadian Sediment Quality Guidelines for the Protection of Aquatic Life (Environment Canada, 1995). The lower level guidelines currently known as the interim sediment quality guidelines were used. Individual metals and organic compounds were normalized to yield a value called a toxicity index. These toxicity indexes were then summed for related groups of contaminants (metals, organochlorine compounds, and PAHs), then plotted (fig. 4). These guidelines use a broadly accepted approach for identifying levels of contaminants in sediment that are expected to adversely affect aquatic life. The guidelines are not related directly to human health. This normalization allows comparison of the relative toxicity of metals, organochlorine compounds, and PAHs.

The graph (fig. 4) shows trends for the three major groups of contaminants measured in the sediment core. The higher the toxicity index, the more toxic the sediment is expected to be-thus, a decrease over time means sediment quality is improving. This graph indicates that the worst overall sediment quality in the past 40 years is associated with the DDT spill in 1961. Overall sediment quality improved from 1961 until about the mid-1980s, mostly because of large decreases in DDT and PCBs, both organochlorine compounds. Since the mid-1980s, however, the sediment toxicity index has been increasing, in large part, because of the large increase in PAHs. This increase in toxicity indicates that improvements in sediment quality caused by reductions in the use of many organochlorine pesticides and PCBs are being offset by increases in PAHs, probably traffic related, as Austin grows.

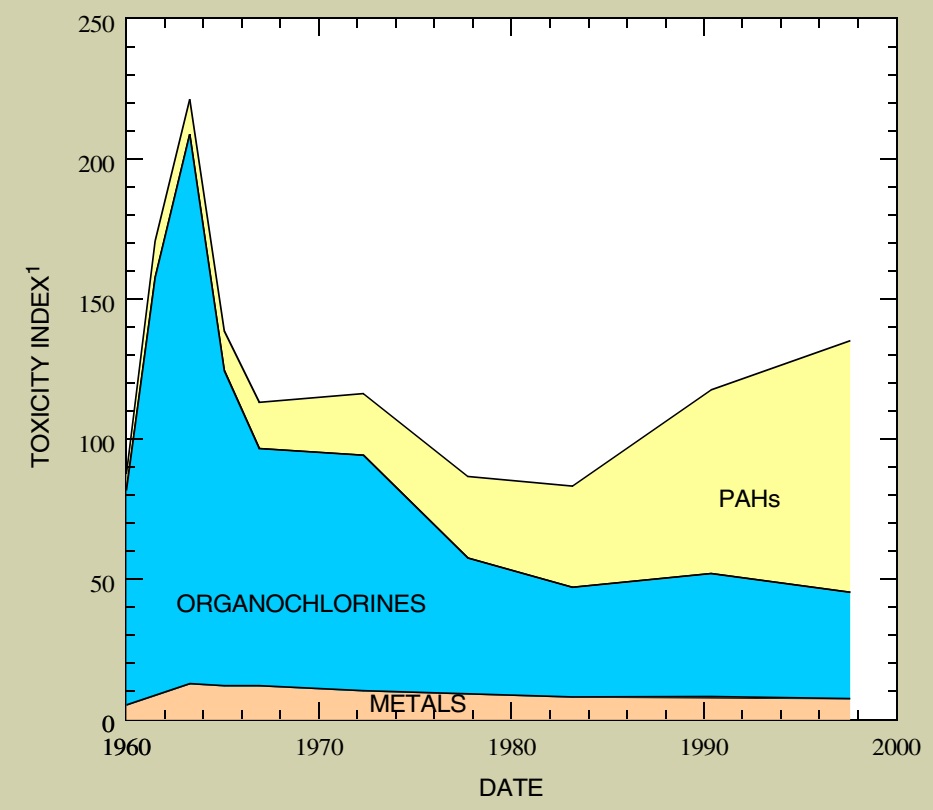

Figure 4. Trends in overall sediment quality in Town Lake.

${ }^{1}$ Toxicity index is computed by dividing contaminant concentrations by the Canadian Sediment Quality Guidelines for the Protection of Aquatic Life (Environment Canada, 1995). 


\section{How We Sample}

Three basic types of coring tools were used: piston corers, gravity corers, and box corers. The piston and gravity corers both collect relatively long (as much as $3.5 \mathrm{~m}), 6$-centimeter $(\mathrm{cm})$ diameter tubes of mud. The box corers collect a sample as much as 1-m long, 14-cm square and have jaws that close at the bottom to hold the sample in. The Town Lake cores were collected from a raft (see picture on left) and, on larger lakes, are collected from a pontoon boat (see picture at bottom). After collection, a core is subsampled by pushing the sediment up through the plastic liner and slicing thin layers of sediment off the top (see picture on right). The chemistry of the samples is measured using various analytical methods. Cesium-137 for age dating is measured by radioactive counting (Van Metre and others, 1998). Metals are measured by inductively-coupled plasma/atomic emission spectroscopy and graphite-furnace atomic adsorption (Fishman and Friedman, 1989). Organic compounds are measured by gas chromatography/ mass spectrometry (Furlong and others, 1994; Foreman and others, 1995). Ages of sediment layers in the Town Lake core were assigned on the basis of the cesium-137 profile and core lithology similar to the approach used by Van Metre and others (1997).

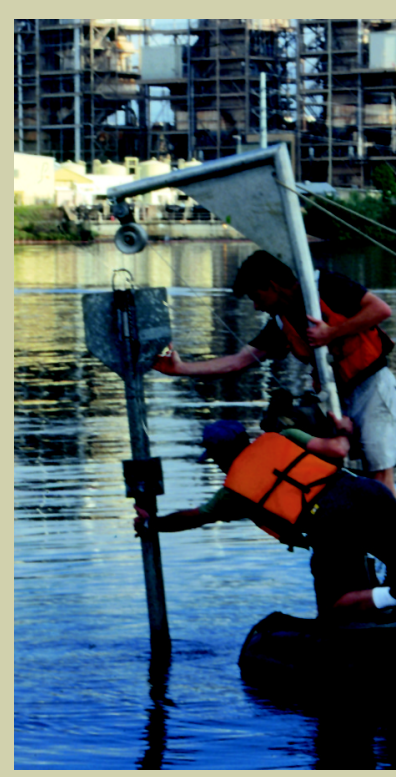

Retrieving a gravity core from the bottom of Town Lake.

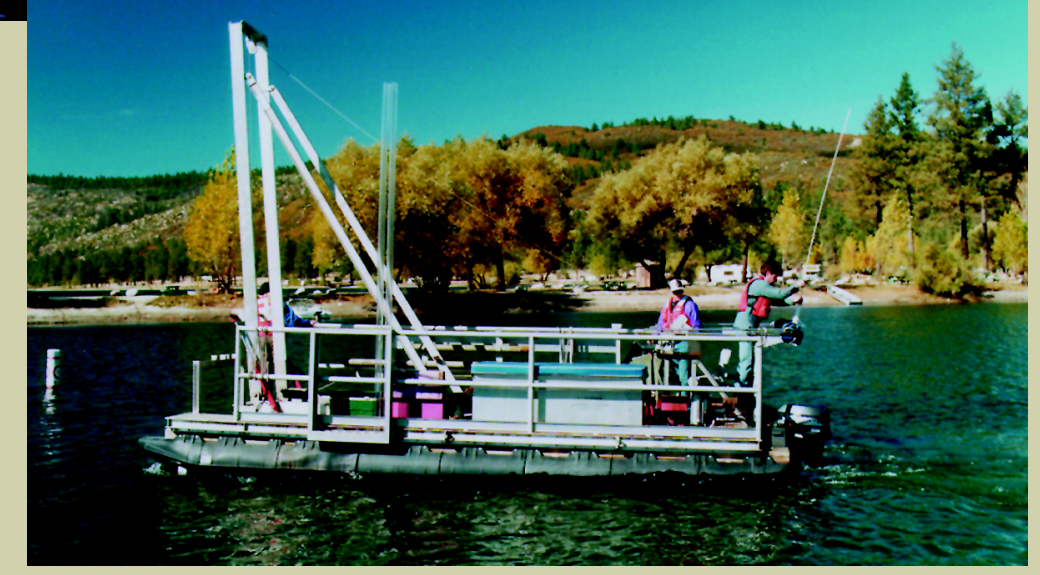

Sampling on a lake in California from the pontoon boat.

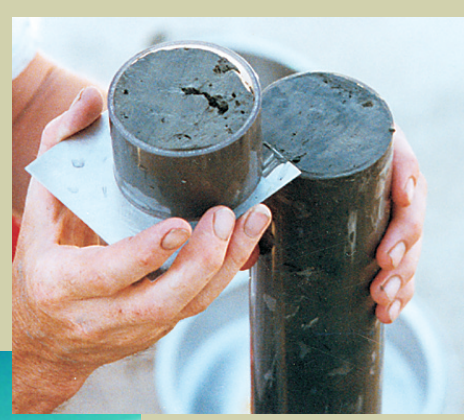

Slicing a 5-centimeter long subsample from a core for laboratory analysis. 


\section{The NAWQA Program}

The Town Lake study was done by the USGS National Water-Quality Assessment (NAWQA) Program's Reconstructed Trends study. More than 50 lakes have been sampled nationally for this study since 1992 (fig. 5). With the exception of the larger-than-normal DDT peak, trends in the Town Lake sediment core are similar to trends in sediment cores from many other U.S. urban lakes. In general, concentrations of regulated and banned contaminants such as DDT, PCBs, and lead have decreased greatly coincident with reductions in use. Chlordane trends in the United States vary regionally, with continued larger concentrations in urban lakes in the South and upper Midwest and decreasing trends in the Northeast (Van Metre and others, 1997, 1998). Trends in some "unregulated" metals and organic compounds are also variable and, in some cases, continue to increase

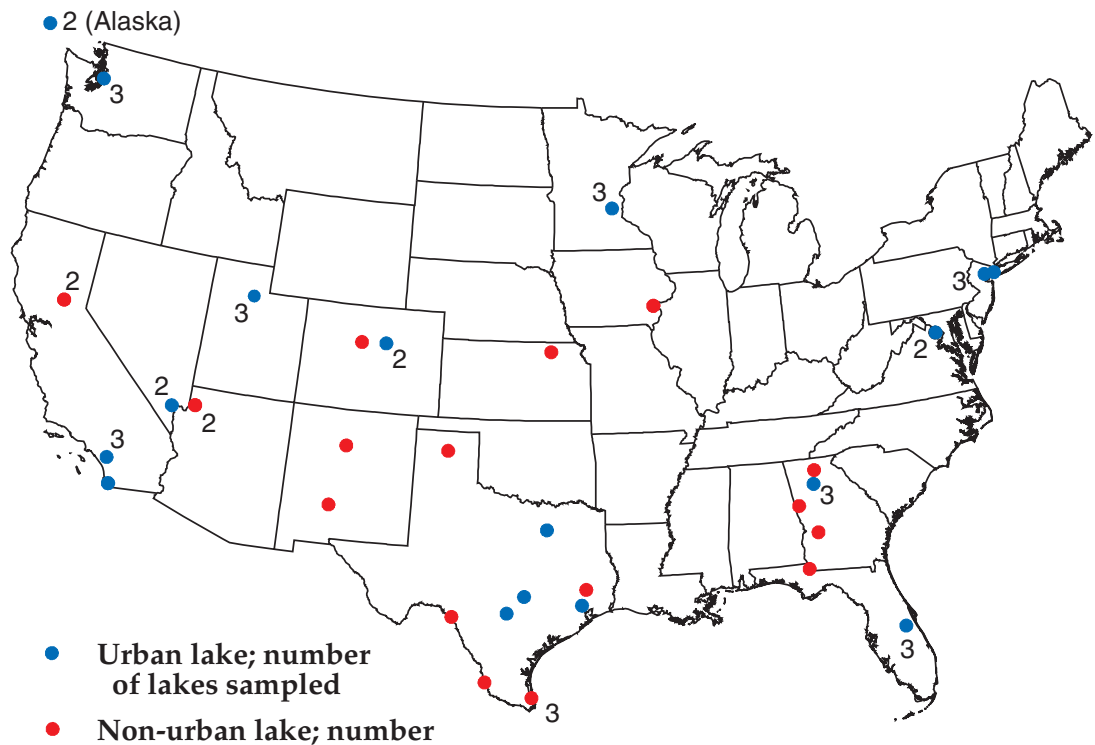

- Non-urban lake; number of lakes sampled

Figure 5. Sites sampled during 1992-99 for the USGS reconstructed trends study.

with urban growth. Arsenic and zinc, for example, are increasing in many lake sediment cores concurrent with urbanization (Van Metre and Callender, 1999). PAH trends, on the other hand, are very consistent in lakes in areas of new urban growth-increasing in all urbanizing lakes where sediment cores have been collected for the NAWQA Program.

\section{References}

Björseth, Alf, and Ramdahl, Thomas, 1985, eds., Handbook of polycyclic aromatic hydrocarbons-v. 2, Emission sources and recent progress in analytical chemistry: New York, Marcel Dekker Inc.

Callender, Edward, and Van Metre, P.C., 1997, Reservoir sediment cores show U.S. lead declines: Environmental Science and Technology, v. 31, no. 9, p. 424A-428A.

Carson, Rachel, 1962, Silent spring: Boston, Houghton Mifflin, 386 p.

Environment Canada, 1995, Interim sediment quality guidelines: Ottowa, Ontario, Ecosystem Conservation Directorate, Evaluation and Interpretation Branch, $63 \mathrm{p}$.

Fishman, M.J., and Friedman, L.C., eds., 1989, Methods for determination of inorganic substances in water and fluvial sediments: U.S. Geological Survey Techniques of Water-Resources Investigations, book 5, chap. A1, $545 \mathrm{p}$.

Foreman, W.T., Connor, B.F., Furlong, E.T., Vaught, D.G., and Merten, L.M., 1995, Methods of analysis by the U.S. Geological Survey National Water Quality Laboratory-Determination of organochlorine pesticides and polychlorinated biphenyls in bottom sediment by dual capillary-column gas chromatography with electron-capture detection: U.S. Geological Survey Open-File Report 94-140, 78 p.

Furlong, E.T., Vaught, D.G., Merten, L.M., Foreman, W.T., Gates, P.M., and Koleis, J.C., 1994, Methods of analysis by the U.S. Geological Survey National Water Quality Laboratory-Determination of semivolatile organic compounds in bottom sediment by solvent extraction, gel permeation chromatographic fractionation, and capillary-column chromatography/mass spectrometry: U.S. Geological Survey Open-File Report 95-719, 67 p.

Long, E.R., and Morgan, L.G., 1990, The potential for biological effects of sediment-sorbed contaminants tested in the National Status and Trends Program: National Oceanic and Atmospheric Administration, Technical Memorandum NOS OMA 52, 175 p.

Schrank, D.L., and Lomax, T.J., 1999, The 1999 annual mobility reportInformation for urban America: College Station, Tex., Texas Transportation Institute, Texas A\&M University, accessed
December 28, 1999, at URL

http://mobility.tamu.edu/study/report.stm

Texas Department of Health, 1996, Fish advisories and bans: Texas Department of Health, Seafood Safety Division, $18 \mathrm{p}$.

Van Metre, P.C., and Callender, Edward, 1999, Trends in sediment quality in response to urbanization, in Morganwalp, D.W., and Buxton, H.T., eds., U.S. Geological Survey Toxic Substances Hydrology Program-Proceedings of the Technical Meeting, Charleston, S.C., March 8-12, 1999-v. 2-Contamination of hydrologic systems and related ecosystems: U.S. Geological Survey Water-Resources Investigations Report 99-4018B, p. 471-475.

Van Metre, P.C., Callender, Edward, and Fuller, C.C., 1997, Historical trends in organochlorine compounds in river basins identified using sediment cores from reservoirs: Environmental Science and Technology, v. 31, no. 8, p. 2,339-2,344.

Van Metre, P.C., Wilson, J.T., Callender, Edward, and Fuller, C.C., 1998, Similar rates of decrease of persistent, hydrophobic and particlereactive contaminants in riverine systems: Environmental Science and Technology, v. 32, no. 21, p. 3,312-3,317.

Whitmore, R.W., Kelly, J.E., and Reading, P.L., 1992. National home and garden pesticide use survey, final report: Research Triangle Institute, $\mathrm{RTI} / 5100 / 17-01 \mathrm{~F}, 140 \mathrm{p}$.

-P.C. Van Metre and B.J. Mahler

Photographs by C.E. Ranzau

Information on technical reports and hydrologic data related to this study can be obtained from:

District Chief

U.S. Geological Survey

8027 Exchange Dr.

Austin, TX 78754-4733

E-mail: dc_tx@usgs.gov

Phone: (512) 927-3500

FAX: (512) 927-3590

World Wide Web: http://tx.usgs.gov/ 